\title{
Effect of operating conditions on the sorption enhanced steam reforming of blends of acetic acid and acetone as bio-oil model compounds
}

G. Esteban-Díez ${ }^{\mathrm{a}}$, María V. Gil ${ }^{\mathrm{b}}$, C. Pevida ${ }^{\mathrm{a}}$, D. Chen ${ }^{\mathrm{b}}$, F. Rubiera ${ }^{\mathrm{a},{ }^{*}}$

${ }^{a}$ Instituto Nacional del Carbón, INCAR-CSIC, Apartado 73, 33080 Oviedo, Spain

${ }^{\mathrm{b}}$ Department of Chemical Engineering, Norwegian University of Science and Technology, Sem Sælands vei 4, Trondheim, NO-7491, Norway

\begin{abstract}
Hydrogen production by sorption enhanced steam reforming (SESR) of bio-oil obtained from the fast pyrolysis of biomass was thermodynamically and experimentally studied by mixing two model compounds, acetic acid (AcH) and acetone (AcCO), in a fluidized bed reactor. In the SESR process the catalytic reforming reaction and $\mathrm{CO}_{2}$ removal by sorption were carried out simultaneously in a single reactor. The SESR of the model compounds and their blends was performed under atmospheric pressure over a $\mathrm{Pd} / \mathrm{Ni}$-Co hydrotalcite-like material (HT) catalyst using dolomite as $\mathrm{CO}_{2}$ sorbent. The effects of the reaction temperature $\left(475-725^{\circ} \mathrm{C}\right)$, steam/C molar ratio and weight hourly space velocity (WHSV) were studied. For the SESR of acetic acid, acetone and their blends it was observed that the $\mathrm{H}_{2}$ yield and $\mathrm{H}_{2}$ concentration increase as the temperature increases, reaching a maximum value, and then they decrease with the temperature. It was also found that the $\mathrm{CH}_{4}$ concentration decreases as the temperature increases, while the $\mathrm{CO}$ and $\mathrm{CO}_{2}$ concentrations increase with the rise in temperature. High steam/C molar ratio values and low WHSV values favor the $\mathrm{H}_{2}$ yield and $\mathrm{H}_{2}$ concentration, while they lead to a decrease in the $\mathrm{CH}_{4}$ concentration. Hydrogen purities as high as 99.2-99.4\% with small amounts of methane, $\mathrm{CO}$ and $\mathrm{CO}_{2}$ were obtained for the SESR of the model compounds of bio-oil and their blends at a temperature of $575^{\circ} \mathrm{C}$ at atmospheric pressure. The effect of temperature on the SESR of the blends of model compounds of bio-oil is similar to that of the individual model compounds studied, except in the fact that lower $\mathrm{H}_{2}$ yield values are obtained by the SESR of the blends (83.3-88.6\%) compared to the individual model compounds (90.2-95.9\%), a decrease which becomes more noticeable as the proportion of acetone in the blend is increased.
\end{abstract}

Keywords: Acetic acid; Acetone; Bio-oil; Fluidized bed; Hydrogen; Sorption enhanced steam reforming (SESR)

\footnotetext{
* Corresponding author. Tel.: +34 985118975; fax: +34 985297662.

E-mail address: frubiera@incar.csic.es (F. Rubiera).
} 


\section{Introduction}

Hydrogen is generally recognized as a clean transportation fuel and energy carrier and it will undoubtedly play an important role in the future global economy. Moreover, hydrogen is an important raw material in the chemical and petroleum industries, since large quantities are used in ammonia synthesizing facilities for urea (fertilizer production), in the refining of crude oil for use in the transportation sector and in methanol production facilities [1]. Most hydrogen is currently produced from fossil fuels, either by means of the steam methane reforming (SMR) of natural gas and other light hydrocarbons or the partial oxidation of heavy oil fractions. One of the main environmental concerns of the world is nowadays the global warming phenomenon that mainly results from fossil fuels burning. This issue along with the depletion of natural fossil fuel reserves and the dependency of human life to energy explain the importance of green energy sources development with the advantages of low emission of pollutants [2]. Thus, there is great interest in the development of technologies for producing hydrogen based on the exploitation of renewable energy sources, such as biomass, since these forms of energy are considered carbon neutral [3].

One of the most promising methods for using biomass to produce $\mathrm{H}_{2}$ is via different routes with intermediate oxygenates production steps that are subsequently reformed. Thus, the fast pyrolysis of biomass is a method that produces bio-oil [4,5], which has a higher energy density and is easier to handle and transport than raw biomass. Bio-oil is a complex mixture of low and high molecular weight oxygenated compounds, such as carboxylic acids, alcohols, aldehydes, ketones and anhydrosugars derived from the carbohydrate fraction of biomass (cellulose and hemicellulose), as well as phenolics and cyclic oxygenates derived from lignin [6]. This means that the bio-oil can be separated into a carbohydrate-derived solution and a lignin-derived fraction. The latter can be used for producing phenolic resins or fuel-blending components, while the aqueous carbohydrate-derived fraction of the bio-oil can be catalytically steam reformed for hydrogen production.

A number of studies on the production of hydrogen via the steam reforming (SR) of model compounds of bio-oil have been reported in the literature [7-15]. During the experiments on the SR of different components of bio-oil in fixed bed reactors, it has been reported that the formation of carbonaceous deposits in the upper layer of the catalyst bed and in the reactor freeboard considerably reduced the reforming time, requiring more frequent catalyst regeneration $[9,12]$. Fluidized bed reactors are commonly used in processes where catalysts need to be continuously regenerated, since they have a higher solids handling capability, a wide feedstock adaptability and permit a uniform mixture of gas and solids. They also provide a better heat and mass transfer, greater temperature uniformity, apart from a low pressure drop and greater catalyst 
effectiveness factors [16]. Such reactors would be appropriate for processing thermally unstable complex liquids obtained from lignocellulosic biomass because of their tendency to decompose thermally and form carbon deposits since in fluidized bed reactors the feedstock is in closer contact with the catalyst particles and carbon deposits on catalyst particles can be gasified more easily.

Ni-based catalysts are commonly used in steam reforming processes of hydrocarbons and, although they have high activity and selectivity to hydrogen, they do not offer sufficient resistance to the deactivation caused by coke deposition on nickel particles. The main problem with the steam reforming of bio-oil concerns the formation of carbonaceous deposits, i.e., coke formation [17,18]. Although noble metal-based catalysts are more expensive than the traditional Ni-based ones, they may be of interest for certain applications where activity per unit volume is important, as in the case of the reforming of bio-oil. Furthermore, it has been demonstrated that the presence of noble metal catalysts reduces selectivity to $\mathrm{CH}_{4}$ and increases the proportion of $\mathrm{CO}$ and $\mathrm{H}_{2}$ in steam reforming processes [7].

The major process for hydrogen production currently used is steam methane reforming (SMR) of natural gas. It involves multiple steps (reformer, high- and low-temperature shift reactors, PSA unit) and severe operation conditions (800-900 ${ }^{\circ} \mathrm{C}, 15-30$ bar). In recent years the concept of combining reaction and separation stages has received increased attention, since it simplifies the chemical processes involved, conserves energy and can improve the product quality and yield [19]. Therefore, some studies on novel systems for low-cost hydrogen production have been carried out, such as the sorption-enhanced steam reforming [20-23] and the chemical looping reforming [24-26]. The sorption enhanced steam reforming (SESR) process for hydrogen production is an emerging alternative technology to SMR based on the integration of the reforming reaction $\left(\mathrm{H}_{2}\right.$ production) and selective separation $\left(\mathrm{CO}_{2}\right.$ sorption) in a single unit operation. In this process, the reactor contains the catalyst required for the reforming process together with a $\mathrm{CO}_{2}$ sorbent for the in situ removal of carbon dioxide from the gaseous phase. Thus, the steam reforming, WGS and $\mathrm{CO}_{2}$ capture reactions are conducted simultaneously in one single reactor under moderate temperature and pressure conditions. Since the $\mathrm{CO}_{2}$ is removed in situ by the sorbent as soon as it is formed, $\mathrm{H}_{2}$ production is favored due to the displacement of the reforming and WGS reaction equilibriums towards higher hydrogen production. $\mathrm{CO}_{2}$ can be removed in situ from the reaction environment using high temperature solid sorbents. Natural CaO-based sorbents, such as limestone and dolomite, are the most commonly used materials for $\mathrm{CO}_{2}$ capture in SESR processes. These materials usually suffer from a decay in their $\mathrm{CO}_{2}$ capture capacity after several cycles of carbonation/regeneration [27], but they are widely used due to their wide availability and very low cost. They are able to react with $\mathrm{CO}_{2}$ at low $\mathrm{CO}_{2}$ partial 
pressures at moderate temperatures and have fast kinetics and good adsorption capacities. If a $\mathrm{CaO}$-based sorbent is used the captured $\mathrm{CO}_{2}$ is converted to a solid carbonate. This sorbent can then be regenerated using temperature or pressure swing desorption to release a relatively pure stream of $\mathrm{CO}_{2}$ suitable for use or sequestration.

The SESR process has been widely studied in the literature using methane [16,28-35] and it has been shown to improve hydrogen production compared to conventional SR. Moreover, some studies have also been published on the SESR of biomass-derived compounds, such as ethanol [36-38], glycerol [39-42], glucose and sorbitol [43], waste cooking oil [44] and pine sawdust [45].

In the present work, the SESR process is proposed as a method to obtain highly pure hydrogen from bio-oil produced from the fast pyrolysis of biomass. A Pd/Ni-Co catalyst derived from a hydrotalcite-like material (HT) is employed in the process, together with dolomite as $\mathrm{CO}_{2}$ sorbent, since it has previously been demonstrated to be an effective catalyst in the sorption enhanced water gas shift process [46] as well as in the sorption enhanced steam gasification of lignocellulosic biomass [47]. Moreover, this catalyst allows a continuous cycling operation, avoiding the need for a catalyst reduction step between the air-regeneration and reforming stages usually necessary to produce active catalyst. This is because Pd promotes the rapid production of $\mathrm{H}_{2}$ and hence an early reduction of the metal oxide phases contained in the catalyst [48].

The steam reforming of pure bio-oil is very difficult due to the extensive formation of coke and catalyst deactivation. Therefore, to ensure the best operation conditions for hydrogen production, the catalytic steam reforming of bio-oil is performed using model compounds that represent its main constituents [49]. The oxygenated model compounds of the components present in the bio-oils produced by the fast pyrolysis of biomass selected for the present study are acetic acid (AcH), as oxygenated model compound of organic acids, and acetone (AcCO), as model compound of carbonyl-containing constituents (mainly aldehydes and ketones). Xie et al. [50] carried out a theoretical thermodynamic analysis of the steam reforming process with and without $\mathrm{CO}_{2}$ sorbent for four typical model compounds of bio-oil (ethanol, acetic acid, acetone, and phenol), although blends of these compounds were not included in the study. Other studies on the SR process of model compounds of bio-oil include one or a few experiments performed after the addition of a $\mathrm{CO}_{2}$ sorbent [51,52], carrying out a preliminary study of the variable (steam/C ratio). Finally, Yan et al. [53] and Xie et al. [54] carried out studies of the SESR process of the aqueous fraction of bio-oil produced from fast pyrolysis of rice hull and corn cob, respectively. Therefore, there are in the literature some useful contributions to the study of the SESR process through the use of model compounds of bio-oil, although the research is still very 
scarce and no studies of the composition of the blends of model compounds of bio-oil has been carried out.

In this paper the behavior of blends of two model compounds commonly found in bio-oil has been investigated. In this way, it will be possible to evaluate at laboratory scale the optimum operating conditions in order to maximize $\mathrm{H}_{2}$ yield, selectivity and purity, and to gather data of $\mathrm{CH}_{4}, \mathrm{CO}$ and $\mathrm{CO}_{2}$ concentrations in the effluent gas.

Therefore, the objective of the present study is to investigate the sorption enhanced steam reforming of blends of two oxygenated model compounds typically found in bio-oils, acetic acid and acetone, in a fluidized bed reactor. $\mathrm{Pd} / \mathrm{Ni}-\mathrm{Co} \mathrm{HT}$ is used as reforming catalyst, while dolomite is used as $\mathrm{CO}_{2}$ sorbent. The influence of the reaction temperature, steam/C feed molar ratio and feed space velocity on $\mathrm{H}_{2}$ production is analyzed. A thermodynamic equilibrium analysis of the process is also performed so that the equilibrium values can be compared with the experimental results.

\section{SESR process of bio-oil}

The reactions involved in the conversion of acetic acid and acetone to hydrogen are shown in Eqs. (1) and (2), respectively, which are a combination of steam reforming and water gas shift (WGS) (Eq. (3)) reactions:

$$
\begin{array}{ll}
\mathrm{C}_{2} \mathrm{H}_{4} \mathrm{O}_{2}+2 \mathrm{H}_{2} \mathrm{O} \rightarrow 4 \mathrm{H}_{2}+2 \mathrm{CO}_{2} & \Delta H_{\mathrm{r}}^{0}=+184 \mathrm{~kJ} \mathrm{~mol}^{-1} \\
\mathrm{C}_{3} \mathrm{H}_{6} \mathrm{O}+5 \mathrm{H}_{2} \mathrm{O} \rightarrow 8 \mathrm{H}_{2}+3 \mathrm{CO}_{2} & \Delta H_{\mathrm{r}}^{0}=+277 \mathrm{~kJ} \mathrm{~mol}^{-1} \\
\mathrm{CO}+\mathrm{H}_{2} \mathrm{O} \leftrightarrow \mathrm{H}_{2}+\mathrm{CO}_{2} & \Delta H_{\mathrm{r}}^{0}=-41 \mathrm{~kJ} \mathrm{~mol}^{-1}
\end{array}
$$

The reforming reaction is highly endothermic, while the shift reaction is moderately exothermic. Both the steam reforming and WGS reactions are reversible, i.e., they are equilibrium limited, and it is not possible to achieve the complete conversion of the model compound in a single reactor. The experimental yield of hydrogen is lower than the stoichiometric maximum value because two undesirable products, $\mathrm{CO}$ and $\mathrm{CH}_{4}$, are also formed via the reverse of the WGS (Eq. (3)) and methanation (Eq. (4)) reactions. In addition, thermal decomposition of the organic compounds contained in the bio-oil may occur at the same time as the reforming reaction and lead to the formation of intermediates and carbonaceous deposits.

$$
\mathrm{CO}+3 \mathrm{H}_{2} \leftrightarrow \mathrm{CH}_{4}+\mathrm{H}_{2} \mathrm{O} \quad \Delta H_{\mathrm{r}}^{0}=-206 \mathrm{~kJ} \mathrm{~mol}^{-1}
$$

The principle behind SESR process is to shift the equilibrium of the reversible reforming and WGS reactions, based on Le Chatelier's principle, in order to enhance hydrogen production via the in situ removal of $\mathrm{CO}_{2}$ from the reaction zone. In this way, a high hydrogen conversion can be obtained in a single step. $\mathrm{CO}_{2}$ removal can be performed using high-temperature solid sorbents. If a CaO-based sorbent is used in the proposed SESR process, it is incorporated into the 
catalyst bed in order to remove the $\mathrm{CO}_{2}$ from the gaseous phase in situ, as shown in Eq. (5):

$$
\mathrm{CaO}_{(\mathrm{s})}+\mathrm{CO}_{2} \leftrightarrow \mathrm{CaCO}_{3(\mathrm{~s})} \quad \Delta H_{\mathrm{r}}^{0}=-178 \mathrm{~kJ} \mathrm{~mol}^{-1}
$$

The $\mathrm{CO}_{2}$ sorbent can capture $\mathrm{CO}_{2}$ repeatedly via consecutive $\mathrm{CaO}$-carbonation and $\mathrm{CaCO}_{3}$-calcination cycles according to the reversible Eq. (5). Due to the equilibrium shift effect caused by the capture of $\mathrm{CO}_{2}$, both the WGS reaction (Eq. (3)) and the $\mathrm{CH}_{4}$ reforming reaction (the reverse of Eq. (4)) are promoted. The WGS reaction is directly promoted by the capture of $\mathrm{CO}_{2}$. This provokes a decrease in the $\mathrm{CO}$ concentration in the gas phase, which will indirectly promote the $\mathrm{CH}_{4}$ reforming reaction. Hence, the $\mathrm{CO}$ and $\mathrm{CH}_{4}$ contents are significantly reduced, which in turn increases the hydrogen concentration in the product gas and allows almost complete conversion to be achieved.

The overall reactions for the sorption enhanced steam reforming (SESR) process of acetic acid and acetone are shown in Eqs. (6) and (7), respectively.

$$
\begin{array}{ll}
\mathrm{C}_{2} \mathrm{H}_{4} \mathrm{O}_{2}+2 \mathrm{H}_{2} \mathrm{O}+2 \mathrm{CaO}_{(\mathrm{s})} \rightarrow 4 \mathrm{H}_{2}+2 \mathrm{CaCO}_{3(\mathrm{~s})} & \Delta H_{\mathrm{r}}^{0}=-172 \mathrm{~kJ} \mathrm{~mol}^{-1} \\
\mathrm{C}_{3} \mathrm{H}_{6} \mathrm{O}+5 \mathrm{H}_{2} \mathrm{O}+3 \mathrm{CaO}_{(\mathrm{s})} \rightarrow 8 \mathrm{H}_{2}+3 \mathrm{CaCO}_{3(\mathrm{~s})} & \Delta H_{\mathrm{r}}^{0}=-257 \mathrm{~kJ} \mathrm{~mol}^{-1}
\end{array}
$$

The complete conversion of acetic acid and acetone by SESR produces 4 and 8 mol of hydrogen, respectively, per mole of model compound.

In the present work, experiments were also conducted with three blends of acetic acid and acetone (3:1, 1:1 and 1:3 $\mathrm{mol} \mathrm{AcH} / \mathrm{mol} \mathrm{AcCO})$. The overall reactions for the SESR of the blends are shown in Eqs. (8), (9) and (10), respectively.

$$
\begin{aligned}
& \mathrm{C}_{2.25} \mathrm{H}_{4.5} \mathrm{O}_{1.75}+2.75 \mathrm{H}_{2} \mathrm{O}+2.25 \mathrm{CaO}_{(\mathrm{s})} \rightarrow 5 \mathrm{H}_{2}+2.25 \mathrm{CaCO}_{3(\mathrm{~s})} \\
& \mathrm{C}_{2.5} \mathrm{H}_{5} \mathrm{O}_{1.5}+3.5 \mathrm{H}_{2} \mathrm{O}+2.5 \mathrm{CaO}_{(\mathrm{s})} \rightarrow 6 \mathrm{H}_{2}+2.5 \mathrm{CaCO}_{3(\mathrm{~s})} \\
& \mathrm{C}_{2.75} \mathrm{H}_{5.5} \mathrm{O}_{1.25}+4.25 \mathrm{H}_{2} \mathrm{O}+2.75 \mathrm{CaO}_{(\mathrm{s})} \rightarrow 7 \mathrm{H}_{2}+2.75 \mathrm{CaCO}_{3(\mathrm{~s})}
\end{aligned}
$$

The complete conversion of the 3:1, 1:1 and 1:3 mol AcH/mol AcCO blends of acetic acid and acetone by SESR produces 5, 6 and 7 mol of hydrogen, respectively, per mole of blend.

During the SESR process the exothermic carbonation reaction supplies most of the heat required by the endothermic reforming reactions. Thus, the combination of the endothermic reforming reaction and exothermic $\mathrm{CO}_{2}$ sorption balances the reactor's energy requirements and the whole reaction/sorption process can be performed at much lower temperatures than in the conventional SR process [32]. In this way, catalyst coking and sintering, as well as investment and operation costs, can be reduced. Nevertheless, it needs to be taken into account that more energy will be required to regenerate the sorbent in the energy-intensive calcination reaction.

\section{Material and methods}

\subsection{Model compounds}

The model compounds of bio-oil from the fast pyrolysis of biomass were acetic acid ( $\mathrm{AcH})$ 
and acetone (AcCO). Glacial acetic acid (100\% purity) and acetone (100\% purity) were supplied by PANREAC. Aqueous solutions were prepared using steam/C molar ratios of 1.5-4.5 for acetic acid and 3.33-6.67 for acetone. Experiments were conducted with both model compounds separately, as well as with three blends of acetic acid and acetone $(3: 1,1: 1$ and 1:3 $\mathrm{mol} \mathrm{AcH} / \mathrm{mol}$ $\mathrm{AcCO})$.

\section{2. $\mathrm{CO}_{2}$ sorbent}

Arctic dolomite was supplied by Franefoss Miljøkalk As, Norway. This has a purity of approximately 98.5 wt.\% $\mathrm{CaMg}\left(\mathrm{CO}_{3}\right)_{2}$ and no sulfur according to X-ray fluorescence analysis. The dolomite was used as a precursor of $\mathrm{CaO}$ for the capture of $\mathrm{CO}_{2}$. Its initial maximum $\mathrm{CO}_{2}$ capture capacity was estimated as being $0.46 \mathrm{~g} \mathrm{CO}_{2} / \mathrm{g}$ sorbent. It was calcined in an air flow (200 $\mathrm{mL} \min ^{-1}$ ) at $800{ }^{\circ} \mathrm{C}$ for $4 \mathrm{~h}$ prior to its storage.

\subsection{Catalyst preparation}

A $1 \% \mathrm{Pd} / 20 \% \mathrm{Ni}-20 \% \mathrm{Co} \mathrm{HT}$ catalyst $(\mathrm{Pd} / \mathrm{Ni}-\mathrm{Co} \mathrm{HT})$ was prepared by means of the incipient wetness impregnation method using a $20 \% \mathrm{Ni}-20 \% \mathrm{Co}$ hydrotalcite-like material (Ni-Co $\mathrm{HT})$ as precursor. The Ni-Co HT precursor was prepared by co-precipitation of $\mathrm{Ni}\left(\mathrm{NO}_{3}\right)_{2} \cdot 6 \mathrm{H}_{2} \mathrm{O}$, $\mathrm{Co}\left(\mathrm{NO}_{3}\right)_{3} \cdot 6 \mathrm{H}_{2} \mathrm{O}, \mathrm{Mg}\left(\mathrm{NO}_{3}\right)_{3} \cdot 6 \mathrm{H}_{2} \mathrm{O}$ and $\mathrm{Al}\left(\mathrm{NO}_{3}\right)_{3} \cdot 9 \mathrm{H}_{2} \mathrm{O}$. A stoichiometric ratio of cations was chosen so as to yield a material with a nominal composition of $20 \% \mathrm{Ni}-20 \% \mathrm{Co}$. The precipitate obtained was filtered, washed, dried overnight and then calcined at $600{ }^{\circ} \mathrm{C}$ for $6 \mathrm{~h}$. A detailed description of the precursor preparation procedure is reported elsewhere [55]. After calcination, the Ni-Co HT precursor was impregnated with a 1\% (w/w) load of Pd. The Pd solution was prepared by dissolving $\mathrm{PdCl}_{2}$ into two equivalents of $\mathrm{HCl}$ and diluting them in ethanol to the desired concentration. The sample was dried for $14 \mathrm{~h}$ at $100^{\circ} \mathrm{C}$ and calcined in an air flow at $500{ }^{\circ} \mathrm{C}$ for $1 \mathrm{~h}$ in a muffle oven at a heating rate of $5^{\circ} \mathrm{C} \min ^{-1}$. A detailed description of the preparation procedure of the $\mathrm{Pd} / \mathrm{Ni}-\mathrm{Co} \mathrm{HT}$ catalyst as well as its characterization is reported elsewhere $[47,48]$. The calcined catalyst was pelletized, ground and sieved to obtain a particle size of $106-212 \mu \mathrm{m}$.

\subsection{Experimental procedure}

A schematic flow diagram of the experimental setup used for the SESR experiments with the model compounds of bio-oil and their blends is shown elsewhere [56]. Briefly, it consists of an updraft bubbling fluidized bed quartz reactor (i.d. $27 \mathrm{~mm}$ ), which in this work was loaded with a $12 \mathrm{~g}$ mixture of calcined dolomite (as $\mathrm{CO}_{2}$ sorbent) and $\mathrm{Pd} / \mathrm{Ni}-\mathrm{Co} \mathrm{HT}$ catalyst, at a sorbent-to-catalyst ratio of $5 \mathrm{~g} / \mathrm{g}$. The reactor is located inside a tubular electric furnace and the 
reaction temperature is controlled by a K-type thermocouple inserted into the bed and connected to a temperature controller and data recorder. Gases are delivered by Bronkhorst ${ }^{\circledR}$ mass flow controllers. The liquid reactant mixture is fed in by means of a Gilson ${ }^{\circledR}$ high-performance liquid chromatography (HPLC) pump from the bottom of the reactor. The aqueous solution of the studied model compound is swept by a nitrogen flow, evaporated in an evaporator and then introduced updraft through the catalyst/sorbent bed as a fluidizing gas.

The SESR experiments were performed under atmospheric pressure and isothermally in the temperature range of $475-725^{\circ} \mathrm{C}$. Prior to each SESR experiment, the catalyst/sorbent mixture was subjected to a regeneration step at $800{ }^{\circ} \mathrm{C}$ in an air flow $\left(200 \mathrm{NmL} \mathrm{min}{ }^{-1}\right)$ until the $\mathrm{CO}_{2}$ level fell to less than 0.1 vol.\%. The regeneration temperature was selected taking into consideration the thermodynamic limitations of the decarbonation reaction and the kinetics of the decarbonation of dolomite. A regenerated catalyst/sorbent mixture was used for all of the SESR experiments in the present study. After regeneration, the reactor was purged with $\mathrm{N}_{2}$ and cooled down to the desired experimental reaction temperature. Once the operating temperature was reached under a $\mathrm{N}_{2}$ atmosphere, the liquid reactant mixture (steam/C $=1.5-6.67$ ) was evaporated, blended with a $50 \mathrm{NmL} \mathrm{min}^{-1} \mathrm{~N}_{2}$ flow (used as internal standard) and then introduced updraft in the reactor at different space velocities (liquid flow rates of 5-20 $\mathrm{g} \mathrm{h}^{-1}$ ). During SESR experiments, the evolution of the gas effluent composition typically consists of three stages: prebreakthrough, breakthrough and post-breakthrough. First, hydrogen production by the SESR process (pre-breakthrough) proceeds until the $\mathrm{CO}_{2}$ sorbent (calcined dolomite) becomes saturated and loses its capacity for $\mathrm{CO}_{2}$ removal (breakthrough). Afterwards, $\mathrm{CO}_{2}$ capture by the sorbent is negligible (post-breakthrough) and a conventional steam reforming (SR) process occurs. In the present work, the data obtained during the pre-breakthrough stage were employed for the study of the SESR process, while data from the post-breakthrough stage were used to study the SR process.

The product gas was passed through a filter and cyclone to be cleaned of any solid particles that may have been elutriated from the bed. The excess steam, model compounds that did not react and all other condensable products and reactant vapors that may have formed were removed from the exiting gas by condensation in a thermoelectric cooling tank. The composition of the dried gas was determined by an on-line gas chromatograph Varian ${ }^{\circledR}$ CP-4900 Micro GC, equipped with a molecular sieve (Molsieve $5 \AA$ ) and HayeSep A columns, and with a thermal conductivity detector (TCD). Helium was used as the carrier gas. The species detected were $\mathrm{H}_{2}$, $\mathrm{CH}_{4}, \mathrm{CO}, \mathrm{CO}_{2}$ and $\mathrm{N}_{2}$ (the $\mathrm{N}_{2}$ was used as internal standard). The product distribution was calculated on the basis of nitrogen-free and dry composition of the gas effluent. The flow rates of the species generated during the experiment were calculated by means of a nitrogen balance, 
since the amount of nitrogen fed in and the composition of the nitrogen evolved are known.

The $\mathrm{H}_{2}$ yield was calculated from Eq. (11). It is defined as the ratio of the amount of $\mathrm{H}_{2}$ in the actual effluent gas to the theoretical amount of hydrogen that could be obtained by complete reforming of the model compound (or blend) to $\mathrm{CO}_{2}$ and $\mathrm{H}_{2}$. In addition, $\mathrm{H}_{2}$ selectivity, $\mathrm{H}_{2}$ purity and the $\mathrm{CH}_{4}, \mathrm{CO}$, and $\mathrm{CO}_{2}$ concentrations were calculated from Eq. (12)-(14), respectively.

$\mathrm{H}_{2}$ yield $(\%)=100 \cdot\left(F_{\mathrm{H} 2} / N \cdot F_{\text {model compound/blend }}\right)$

$\mathrm{H}_{2}$ selectivity $(\%)=100 \cdot\left[2 \cdot y_{\mathrm{H} 2} /\left(2 \cdot y_{\mathrm{H} 2}+4 \cdot y_{\mathrm{CH} 4}\right)\right]$

$\mathrm{H}_{2}$ purity $($ vol. $\%)=100 \cdot\left(y_{\mathrm{H} 2} / \Sigma_{i} y_{i}\right)$

$\mathrm{CH}_{4} / \mathrm{CO} / \mathrm{CO}_{2}(\operatorname{vol} . \%)=100 \cdot\left(y_{\mathrm{CH} 4 / \mathrm{CO} / \mathrm{CO} 2} / \Sigma_{i} y_{i}\right)$

where $F_{\mathrm{H} 2}$ is the molar flow rate of the $\mathrm{H}_{2}$ produced $\left(\mathrm{mol} \mathrm{min}^{-1}\right), N$ is the number of moles of $\mathrm{H}_{2}$ theoretically produced per mol of model compound ( 4 for acetic acid and 8 for acetone) or per mol of blend (5, 6 and 7 for 3:1, 1:1 and 1:3 mol AcH/mol AcCO blends, respectively), $F_{\text {model }}$ compound/blend is the molar flow rate of the model compound or blend fed in $\left(\mathrm{mol} \mathrm{min}^{-1}\right)$, and $y_{i}$ is the molar content $\left(\mathrm{N}_{2}\right.$ free and on a dry basis) of each species $i\left(\mathrm{H}_{2}, \mathrm{CH}_{4}, \mathrm{CO}\right.$ and $\left.\mathrm{CO}_{2}\right)$. The weight hourly space velocity (WHSV) is defined as the ratio of the mass flow rate of the inlet model compound or blend to the mass of catalyst ( $g_{\text {model compound/blend }} \mathrm{g}_{\text {catalyst }}{ }^{-1} \mathrm{~h}^{-1}$ ).

\subsection{Thermodynamic equilibrium calculations}

Thermodynamic analysis of the SESR process was conducted under the reaction conditions used in the experimental study. The equilibrium composition was estimated by minimizing the Gibbs free energy of the system using Aspen Plus 7.2 software (Aspentech). The RGibbs reactor was specified as the reaction system and the Peng-Robinson thermodynamic package as the property method. The species produced in concentrations higher than $10^{-4} \mathrm{~mol} \%$ were $\mathrm{H}_{2}, \mathrm{CO}$, $\mathrm{CO}_{2}, \mathrm{CH}_{4}, \mathrm{H}_{2} \mathrm{O}, \mathrm{CaO}$ and $\mathrm{CaCO}_{3} . \mathrm{C}_{2} \mathrm{H}_{4}, \mathrm{C}_{2} \mathrm{H}_{6}$ and $\mathrm{C}$ (graphite as solid carbon) were also included in the product pool, but their concentrations in the equilibrium stream were negligible or not high enough to be considered as significant products, as pointed out in previous works [36]. The product mole fractions were calculated on a dry basis. 


\section{Results and discussion}

\subsection{Effect of the temperature on the SESR of AcH and AcCO}

The effect of the temperature on the SESR of the individual model compounds of the biooil studied ( $\mathrm{AcH}$ and $\mathrm{AcCO})$ was evaluated at atmospheric pressure in the temperature range of $475-725^{\circ} \mathrm{C}$. The experimental steam/C molar ratio used was three times higher than the stoichiometric steam/C molar ratio of the each model compound, i.e., steam/C=3 for acetic acid and steam $/ \mathrm{C}=5$ for acetone. This corresponds to WHSV values of $0.8929 \mathrm{~h}^{-1}$ for acetic acid and $0.4423 \mathrm{~h}^{-1}$ for acetone.

\subsubsection{SESR process}

Fig. 1 shows the $\mathrm{H}_{2}$ yield, $\mathrm{H}_{2}$ selectivity, as well as $\mathrm{H}_{2}, \mathrm{CH}_{4}, \mathrm{CO}$ and $\mathrm{CO}_{2}$ concentrations as a function of the temperature during the SESR of AcH and AcCO. The filled circles represent the experimental results for the SESR process, whereas the solid lines show the equilibrium values obtained from the thermodynamic analysis at equivalent conditions.

The results show that the temperature has a significant effect on the SESR process. As the reaction temperature increases, the $\mathrm{H}_{2}$ yield (Fig. 1a) increases and reaches a maximum at $625^{\circ} \mathrm{C}$ for $\mathrm{AcH}(92.44 \%)$ and at $575^{\circ} \mathrm{C}$ for $\mathrm{AcCO}(95.90 \%)$. After that, the $\mathrm{H}_{2}$ yield gradually decreases as the temperature increases. The $\mathrm{H}_{2}$ selectivity (Fig. 1b) shows high values $(>99.3 \%)$ at temperatures of $575-675^{\circ} \mathrm{C}$ for $\mathrm{AcH}$. For $\mathrm{AcCO}$, it presents very high values $(>99.7 \%)$ at the temperatures studied. The $\mathrm{H}_{2}$ concentration (Fig. 1c) also increases with temperature and reaches a maximum value at $575^{\circ} \mathrm{C}$ for $\mathrm{AcH}(99.29 \%)$ and at $525^{\circ} \mathrm{C}$ in the case of $\mathrm{AcCO}(99.75 \%)$. After that, it decreases significantly as the temperature increases. The experimental $\mathrm{H}_{2}$ selectivity values and $\mathrm{H}_{2}$ concentrations follow the lines of the equilibrium quite closely between 525$725^{\circ} \mathrm{C}$. However, the experimentally obtained $\mathrm{H}_{2}$ yield values are lower than those corresponding to the SESR equilibrium in the range of temperatures studied. On the other hand, the $\mathrm{H}_{2}$ yield, $\mathrm{H}_{2}$ selectivity and $\mathrm{H}_{2}$ concentration show the lowest values at the temperature of $475{ }^{\circ} \mathrm{C}$ for both model compounds.

The $\mathrm{CH}_{4}$ concentration (Fig. 1d) shows very high values at $475{ }^{\circ} \mathrm{C}$ for both model compounds (7.45\% and 5.48\% for $\mathrm{AcH}$ and $\mathrm{AcCO}$, respectively). A high $\mathrm{CH}_{4}$ concentration at low temperatures has previously been reported in sorption enhanced experiments with sorbitol [43] and glycerol [40] due to the fact that the steam methane reforming reaction is favored at high temperatures, which indicates that $\mathrm{CH}_{4}$ is the main impurity found in the product gas at low temperature. The $\mathrm{CH}_{4}$ concentration decreases as the temperature increases: from $1.75 \%$ to $0.15 \%$ between $525^{\circ} \mathrm{C}$ and $675^{\circ} \mathrm{C}$ in the case of the $\mathrm{AcH}$, and from $0.14 \%$ to $0.02 \%$ between $525^{\circ} \mathrm{C}$ and $725^{\circ} \mathrm{C}$ in the case of the $\mathrm{AcCO}$, following closely the lines of equilibrium. The 
methanation reaction becomes thermodynamically unfavorable and steam methane reforming is kinetically enhanced as the temperature increases, which results in low $\mathrm{CH}_{4}$ concentrations at higher temperatures. The lower $\mathrm{CH}_{4}$ concentrations detected in the experiments at temperatures higher than $525^{\circ} \mathrm{C}$ indicate the ability of the $\mathrm{Pd} / \mathrm{Co}-\mathrm{Ni} \mathrm{HT}$ catalyst to suppress the methanation reaction and to successfully catalyze the methane steam reforming reaction during the SESR process. The suppression of the methanation reaction will be favored by the enhancement of the WGS reaction (by the $\mathrm{CO}_{2}$ capture by the sorbent), since when the WGS is promoted and the $\mathrm{CO}$ concentration is then decreased, the methane reforming reaction will be indirectly promoted (reverse of Eq. 4). This will be a consequence of the integration of both phenomena, reaction and sorption, involved in the SESR process.

As in the case of the $\mathrm{CH}_{4}$ content, the experimental $\mathrm{CO}$ concentration value (Fig. 1e) is situated above the equilibrium lines at the temperature of $475^{\circ} \mathrm{C}$ for both model compounds ( $1.89 \%$ and $0.22 \%$ for $\mathrm{AcH}$ and $\mathrm{AcCO}$, respectively). After that, the $\mathrm{CO}$ concentration increases from $0.04 \%$ to $2.81 \%$ as the temperature increases from $525^{\circ} \mathrm{C}$ to $675^{\circ} \mathrm{C}$ for $\mathrm{AcH}$, and from $0.02 \%$ to $6.52 \%$ as the temperature increases from $525^{\circ} \mathrm{C}$ to $725^{\circ} \mathrm{C}$ for $\mathrm{AcCO}$, reasonably close to the lines of the equilibrium. The $\mathrm{CO}_{2}$ concentration (Fig. 1f) is also high $(2.56 \%)$ at the temperature of $475^{\circ} \mathrm{C}$ for $\mathrm{AcH}$, while it increases from $0.11 \%$ to $6.10 \%$ as the temperature increases from $525^{\circ} \mathrm{C}$ to $675^{\circ} \mathrm{C}$, again very close to the equilibrium lines.

In the case of $\mathrm{AcCO}$, it increases from $0.06 \%$ to $17.61 \%$ as the temperature increases from $475^{\circ} \mathrm{C}$ to $725^{\circ} \mathrm{C}$, close to the equilibrium lines. The favorable thermodynamics of the WGS reaction (exothermic) at low temperature explains the lower CO concentrations found at lower temperatures. Likewise, the favorable thermodynamics of the carbonation reaction (exothermic) at low temperature explains why the $\mathrm{CO}_{2}$ concentration increases with increasing temperature since high temperatures inhibit the removal of $\mathrm{CO}_{2}$ to some extent. A very weak $\mathrm{CO}_{2}$ removal leads to a poor sorption enhancement of the process. Since $\mathrm{CO}_{2}$ sorption implies an enhanced $\mathrm{H}_{2}$ production because the equilibrium of both the steam reforming and WGS reactions are shifted to the product side, lower values of $\mathrm{H}_{2}$ concentration and higher $\mathrm{CO}$ concentrations are detected at the higher temperature range studied. The poor results obtained when the SESR process is carried out at $475^{\circ} \mathrm{C}$ could be due to the slow steam reforming and $\mathrm{CO}_{2}$ capture rates. The kinetic limitations at such a low temperature, lead to a lower level of hydrogen production. It has been demonstrated that the SESR reaction, because of its very nature, is highly dependent on the rate of $\mathrm{CO}_{2}$ removal by the sorbent $[36,57]$. 

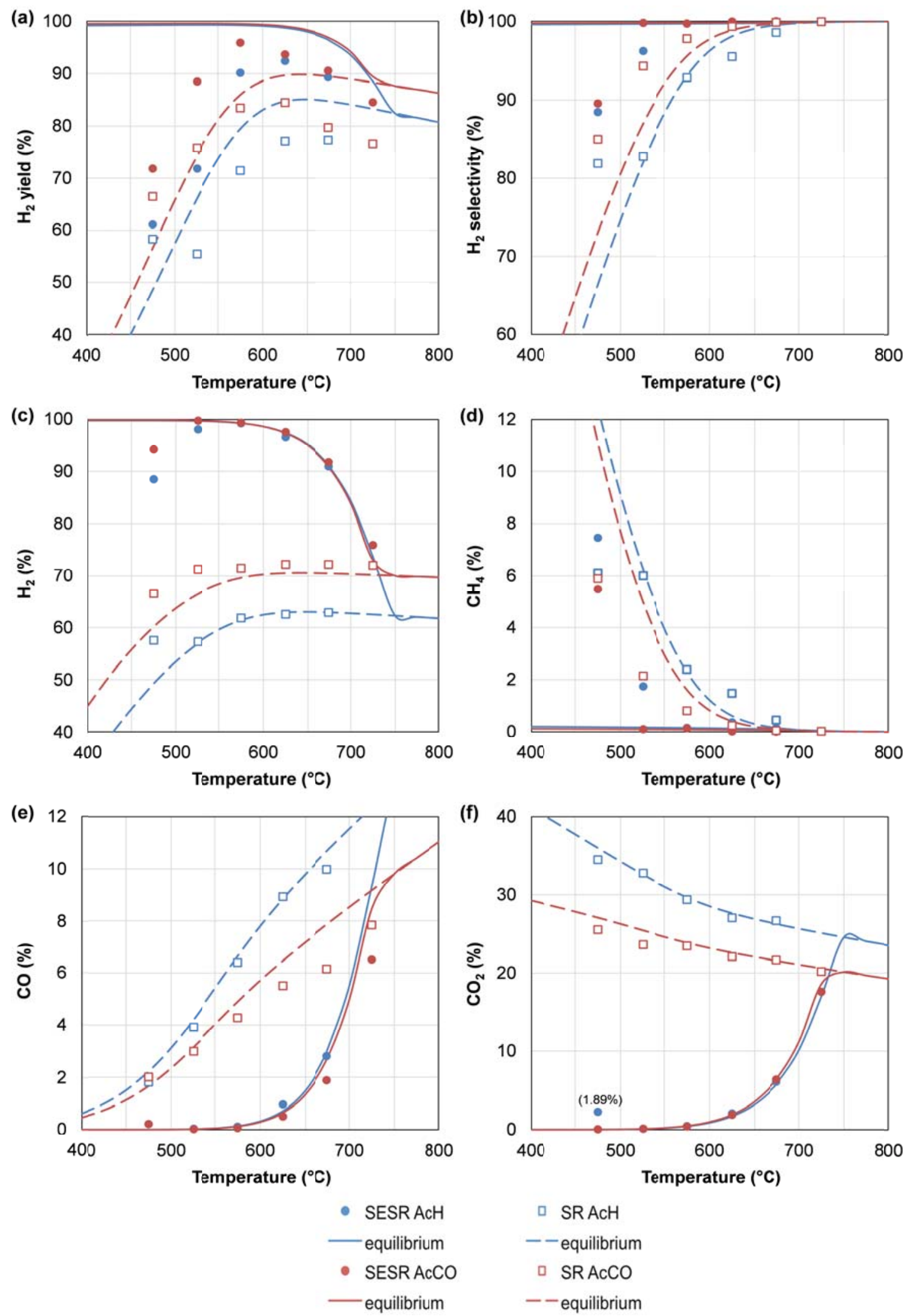

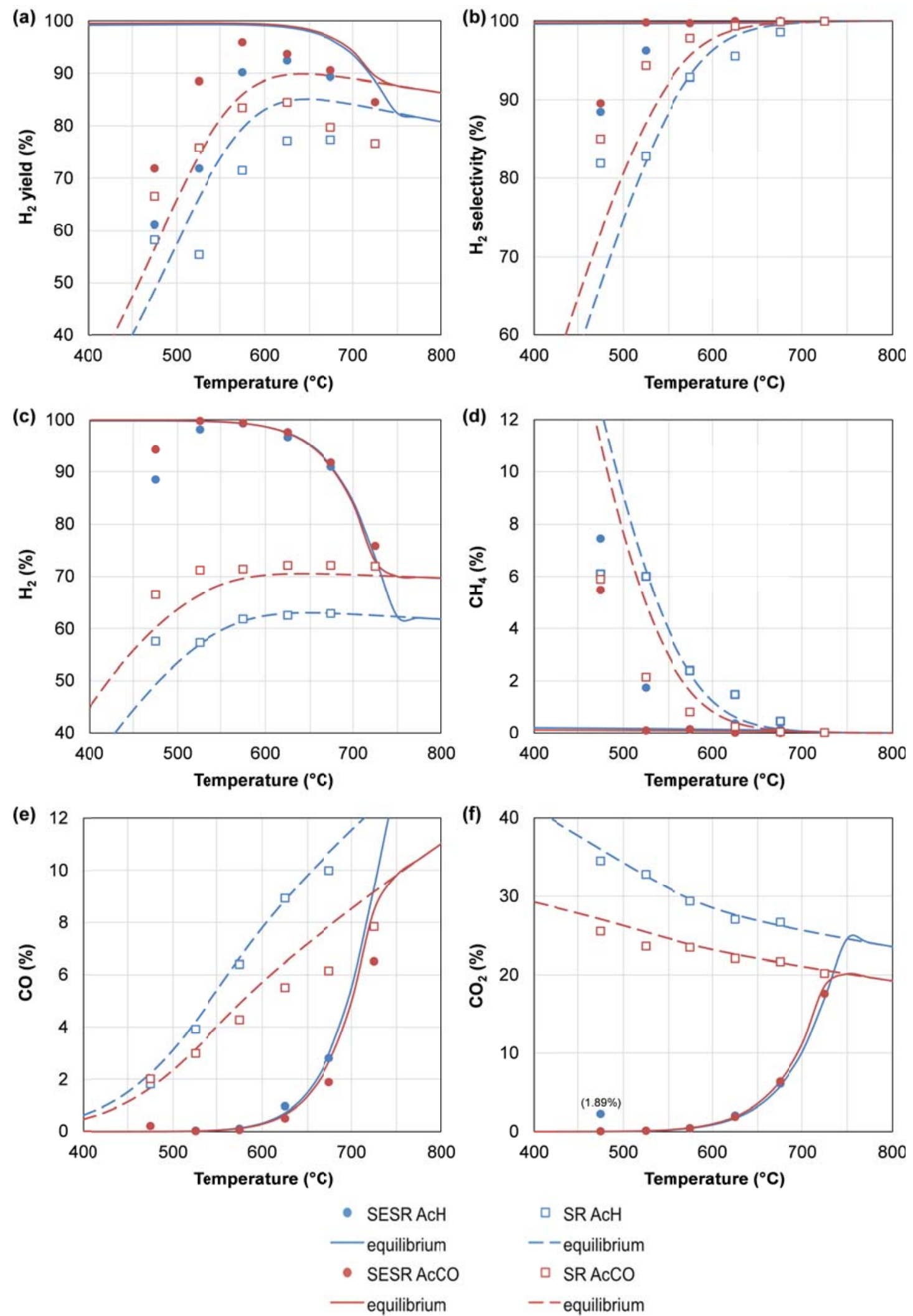

Fig. 1. Effect of the reaction temperature on the $\mathrm{H}_{2}$ yield (a), $\mathrm{H}_{2}$ selectivity (b) and $\mathrm{H}_{2}(\mathrm{c}), \mathrm{CH}_{4}$ (d), $\mathrm{CO}(\mathrm{e})$ and $\mathrm{CO}_{2}$ (f) concentrations during the SESR of $\mathrm{AcH}$ and $\mathrm{AcCO}$. Reaction conditions: steam $/ \mathrm{C}_{\mathrm{AcH}}=3 \mathrm{~mol} / \mathrm{mol}$, $\mathrm{WHSV}_{\mathrm{AcH}}=0.8929 \mathrm{~h}^{-1}$, steam $/ \mathrm{C}_{\mathrm{AcCO}}=5 \mathrm{~mol} / \mathrm{mol}, \mathrm{WHSV}_{\mathrm{AcCO}}=0.4423 \mathrm{~h}^{-1}$, sorbent $/$ catalyst ratio $=5 \mathrm{~g} / \mathrm{g}, \mathrm{Pd} / \mathrm{Ni}-\mathrm{Co} \mathrm{HT}$ catalyst and dolomite as sorbent. 
If the results for $\mathrm{AcH}$ and $\mathrm{AcCO}$ are compared (Fig. 1), it will be observed that slightly higher values for $\mathrm{H}_{2}$ yield, $\mathrm{H}_{2}$ selectivity and $\mathrm{H}_{2}$ concentration, as well as slightly lower $\mathrm{CO}$ and $\mathrm{CH}_{4}$ concentrations, were obtained in the SESR of AcCO than in the case of $\mathrm{AcH}$ at temperatures below $600{ }^{\circ} \mathrm{C}$. These results suggest that the reactivity of AcCO is higher than that of AcH in SESR. The effect of the molecular identity of biomass-derived oxygenates on the activity under aqueous phase reforming has recently been reviewed and it has been concluded that the more reduced molecules (i.e. less $\mathrm{OH}$ groups) are easier to undergo $\mathrm{C}-\mathrm{C}$ cleavage, although the effect of the molecule length could not be excluded [58]. The molecular structure dependence of the activity deduced from the results in the present work is in good agreement with the observed general trend.

Finally, in order to establish the optimum condition for the SESR of AcH and AcCO, it should be taken into account that the different trends observed for the $\mathrm{H}_{2}$ yield and $\mathrm{H}_{2}$ concentration values as the temperature increases suggests the need for a compromise between these parameters to select the best temperature for the SESR process. Thus, in the present study it can be concluded that a temperature of $575^{\circ} \mathrm{C}$ is optimum for the SESR of acetic acid and acetone. High $\mathrm{H}_{2}$ purity (99.3-99.4\%) and high $\mathrm{H}_{2}$ yields (90.2-95.9\%), together with low concentrations of $\mathrm{CH}_{4}, \mathrm{CO}$ and $\mathrm{CO}_{2}$, can be achieved using steam/C ratios of 3 for $\mathrm{AcH}$ and 5 for AcCO, as well as WHSV values of $0.8929 \mathrm{~h}^{-1}$ for $\mathrm{AcH}$ and $0.4423 \mathrm{~h}^{-1}$ for AcCO.

\subsubsection{SR process}

Fig. 1 also shows the $\mathrm{H}_{2}$ yield, $\mathrm{H}_{2}$ selectivity, as well as $\mathrm{H}_{2}, \mathrm{CH}_{4}, \mathrm{CO}$ and $\mathrm{CO}_{2}$ concentrations as a function of the temperature during the SR of the individual model compounds. The blank squares represent the experimental results of the SR process, whereas the dashed lines show the equilibrium values obtained from the thermodynamic analysis at equivalent conditions.

It can be observed that the $\mathrm{H}_{2}$ yield (Fig. 1a), $\mathrm{H}_{2}$ selectivity (Fig. 1b), $\mathrm{H}_{2}$ concentration (Fig. 1c) and CO concentration (Fig. 1e) increase as the experimental temperature increases. This was to be expected since as a result of the endothermic character of the reforming reaction, higher temperatures favor the conversion of fuel resulting in a higher $\mathrm{H}_{2}$ concentration. On the other hand, the $\mathrm{CH}_{4}$ (Fig. 1d) and $\mathrm{CO}_{2}$ concentrations (Fig. 1f) decrease with temperature. The exothermic character of the WGS reaction leads to higher concentrations of CO and lower concentrations of $\mathrm{CO}_{2}$ at higher temperatures. This is due to the fact that the equilibrium of the reaction is shifted to the left, i.e., the reverse of WGS occurs resulting in the consumption of $\mathrm{H}_{2}$ and the production of $\mathrm{CO}$. The endothermic reforming reaction of $\mathrm{CH}_{4}$ explains its lower concentration at higher temperatures. 
Similar results to those of the SESR process were obtained by SR in relation to the thermodynamic equilibrium. Thus, the approach towards equilibrium between the temperatures of $525-675^{\circ} \mathrm{C}$ is reasonably good in respect of $\mathrm{H}_{2}$ selectivity and the $\mathrm{H}_{2}, \mathrm{CH}_{4}, \mathrm{CO}$ and $\mathrm{CO}_{2}$ concentrations, whereas the experimental $\mathrm{H}_{2}$ yield values are slightly lower than those of the SR equilibrium. In the case of the $\mathrm{SR}$ of $\mathrm{AcH}$ and $\mathrm{AcCO}$ at $475^{\circ} \mathrm{C}$, the values corresponding to $\mathrm{H}_{2}$ yield, $\mathrm{H}_{2}$ selectivity and the $\mathrm{H}_{2}$ concentration are slightly higher than those obtained at the equilibrium. This could be due to the fact that $\mathrm{CO}_{2}$ capture continues at a low degree during the SR process, because the $\mathrm{CO}_{2}$ content is slightly lower than that of the equilibrium at this temperature. The activity dependence on the molecular structure is much clearer in the case of $\mathrm{SR}$, where the produced hydrogen is higher from $\mathrm{AcCO}$ compared to from $\mathrm{AcH}$ at all the temperatures studied (Figure 1c).

\subsection{Effect of the steam/C molar ratio on the SESR of AcH and AcCO}

The effect of the steam/C molar ratio on the SESR of $\mathrm{AcH}$ and $\mathrm{AcCO}$ was evaluated at atmospheric pressure and at $575^{\circ} \mathrm{C}$. The steam/C molar ratios ranged from 1.5 to 4.5 for $\mathrm{AcH}$ and from 3.33 to 6.67 for AcCO. Thus, the space velocity of the compounds studied was varied (WHSV $=0.6757-1.3158 \mathrm{~h}^{-1}$ for $\mathrm{AcH}$ and $\mathrm{WHSV}=0.3327-0.6594 \mathrm{~h}^{-1}$ for AcCO) to ensure the same total inlet liquid flow rate $\left(5 \mathrm{~g} \mathrm{~h}^{-1}\right)$. Fig. 2 shows the $\mathrm{H}_{2}$ yield, $\mathrm{H}_{2}$ selectivity, as well as the $\mathrm{H}_{2}, \mathrm{CH}_{4}, \mathrm{CO}$ and $\mathrm{CO}_{2}$ concentrations as a function of the steam/C molar ratio. The filled circles represent the experimental results of the SESR process, whereas the blank squares show the experimental results of SR. Likewise, the solid lines show the equilibrium values at equivalent conditions obtained from the thermodynamic analysis applied in the SESR process, while the dashed lines correspond to the SR process.

As expected for both SESR and SR processes, higher steam/C molar ratios increase the $\mathrm{H}_{2}$ yield, $\mathrm{H}_{2}$ selectivity and $\mathrm{H}_{2}$ concentration, whereas they reduce the $\mathrm{CH}_{4}$ and $\mathrm{CO}$ concentrations. The $\mathrm{CO}_{2}$ concentration increases slightly with the steam/C molar ratio. Low steam/C ratios enhance methanation, while they decrease methane steam reforming and WGS reactions simultaneously [46]. Consequently the $\mathrm{CH}_{4}$ concentration decreases as the steam/ $\mathrm{C}$ molar ratio increases. The $\mathrm{CH}_{4}$ content is an important factor for determining hydrogen selectivity during the SESR process. Moreover, with a low steam/C molar ratio, hydrogen purity is also strongly influenced by the methane content in the effluent gas. 

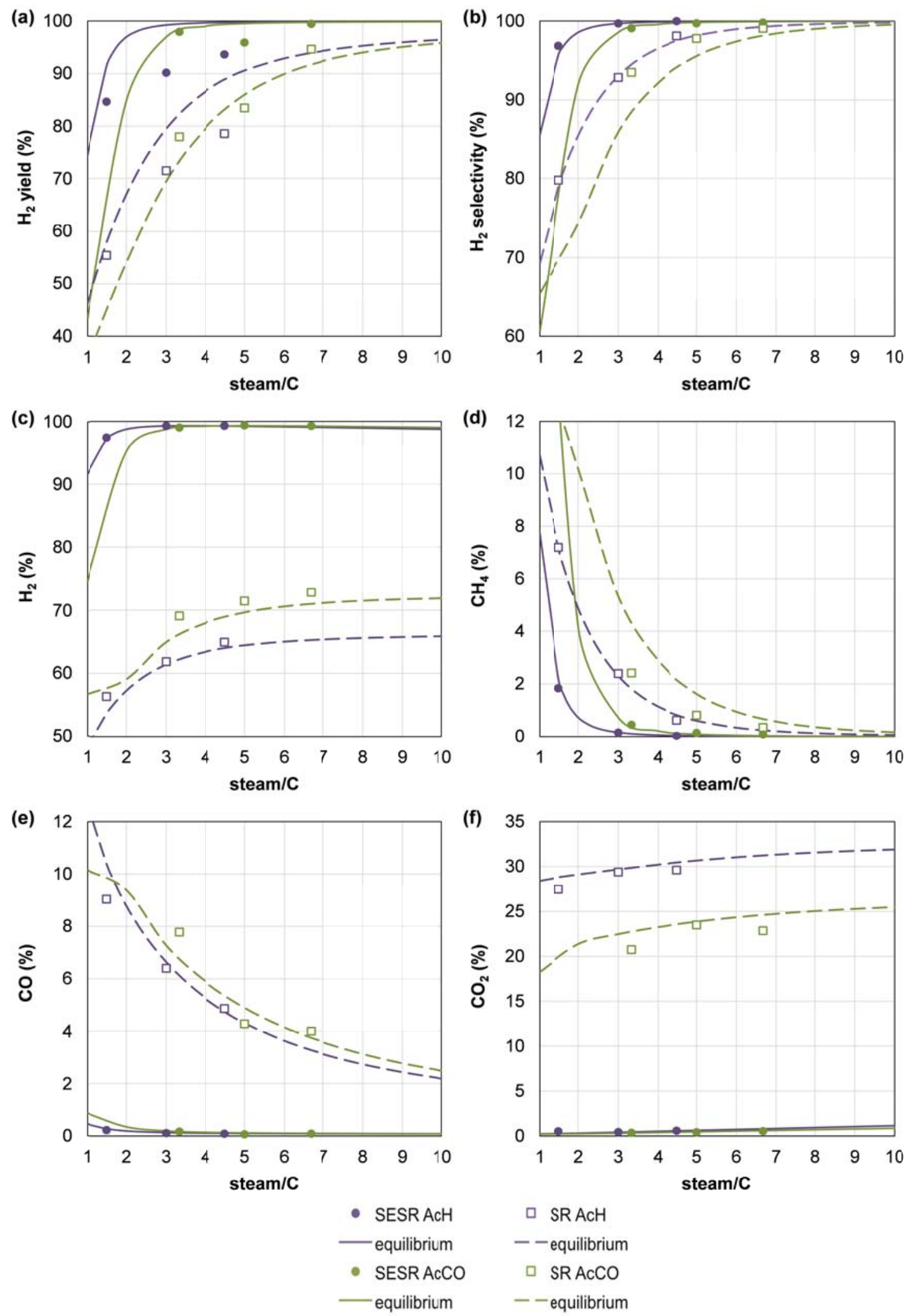

Fig. 2. Effect of the steam/C molar ratio on the $\mathrm{H}_{2}$ yield (a), $\mathrm{H}_{2}$ selectivity (b) and $\mathrm{H}_{2}$ (c), $\mathrm{CH}_{4}$ (d), $\mathrm{CO}$ (e) and $\mathrm{CO}_{2}$ (f) concentrations during the SESR of AcH and AcCO. Reaction conditions: $575^{\circ} \mathrm{C}, \mathrm{WHSV}_{\mathrm{AcH}}=0.6757-1.3158 \mathrm{~h}^{-1}$, WHSV $_{\text {AcCO }}=0.3327-0.6594 \mathrm{~h}^{-1}$, sorbent $/$ catalyst ratio $=5 \mathrm{~g} / \mathrm{g}, \mathrm{Pd} / \mathrm{Ni}-\mathrm{Co}$ HT catalyst and dolomite as sorbent. 
Steam is often added beyond the stoichiometric limit in reforming processes to promote hydrogen productivity and to prevent coking. Carbon deposition, due to polymerization or thermal decomposition, occurs if the gas does not contain a sufficient amount of oxidizing component such as $\mathrm{H}_{2} \mathrm{O}$, resulting in blockage of the catalyst pores [42]. An excess of steam is known to be beneficial for the suppression of coking in steam reforming processes because it leads to the partial gasification of the carbon formed, enhancing the conversion of tars and intermediate compounds [12]. A high steam/C molar ratio is favorable from a thermodynamic point of view, but its value will be limited by the energy cost of the system due to the extra amount of steam generated [59]. Also high steam concentrations will undermine the energy efficiency of the process [42].

The results of the present work, indicate that in SESR catalyst activity is high at a minimum steam/C molar ratio of 3 for $\mathrm{AcH}$ and 5 for $\mathrm{AcCO}$, since in these conditions the $\mathrm{H}_{2}$ concentration shows a high value, together with acceptable $\mathrm{H}_{2}$ yield values and low $\mathrm{CH}_{4}$ and $\mathrm{CO}$ contents.

\subsection{Effect of the weight hourly space velocity (WHSV) on the SESR of AcH and AcCO}

The effect of the space velocity on the SESR of AcH and AcCO was evaluated under atmospheric pressure and at $575{ }^{\circ} \mathrm{C}$. The WHSV ranges studied were $0.8929-2.6786 \mathrm{~h}^{-1}$ for AcH and $0.4423-1.7691 \mathrm{~h}^{-1}$ for AcCO. These values were experimentally obtained by changing the total inlet flow rate $\left(5-20 \mathrm{~g} \mathrm{~h}^{-1}\right)$ while maintaining the steam/C molar ratio at 3 for $\mathrm{AcH}$ and 5 for AcCO. Fig. 3 shows the $\mathrm{H}_{2}$ yield, $\mathrm{H}_{2}$ selectivity, and the $\mathrm{H}_{2}, \mathrm{CH}_{4}, \mathrm{CO}$ and $\mathrm{CO}_{2}$ concentrations as a function of the WHSV. The filled circles represent the experimental results of the SESR process, whereas the blank squares show the experimental results of SR. The solid and dashed lines represent the equilibrium values obtained under equivalent conditions from the thermodynamic analysis of the SESR and SR processes, respectively.

In general in the SESR process at atmospheric pressure, the $\mathrm{H}_{2}$ selectivity and the $\mathrm{H}_{2}, \mathrm{CH}_{4}$, $\mathrm{CO}$ and $\mathrm{CO}_{2}$ concentrations do not vary significantly in the space velocity range studied, although a slight decrease in the $\mathrm{H}_{2}$ selectivity and $\mathrm{H}_{2}$ concentration together with an increase in the $\mathrm{CH}_{4}$ concentration, is observed at the highest space velocity used for AcH $\left(2.6786 \mathrm{~h}^{-1}\right)$. However, the $\mathrm{H}_{2}$ yield decreases significantly with the space velocity. The shorter contact time at higher WHSV values can be expected to cause a lower conversion of fuel. From the results, it can be seen that the $\mathrm{H}_{2}$ yield is affected much more by WHSV than the $\mathrm{H}_{2}$ selectivity and $\mathrm{H}_{2}$ purity, which suggests that, together with a decrease in conversion, an increase in the formation of coke might have occurred at higher space velocities. A sharp decrease in $\mathrm{H}_{2}$ yield as the space velocity increases was also detected in the SESR experiments with glycerol [41], indicating a 
low reaction rate in the feedstock. Selection of an appropriate space velocity in the SESR process should ensure the largest possible supply of feedstock in order to maximize $\mathrm{H}_{2}$ production and minimize the reactor size and the amount of catalyst required [60]. In the present work, acceptable $\mathrm{H}_{2}$ yield values of $85.35 \%$ and $89.31 \%$ were obtained for $\mathrm{AcH}$ and $\mathrm{AcCO}$, respectively, with relatively high WHVS values $\left(1.7858 \mathrm{~h}^{-1}\right.$ for $\mathrm{AcH}$ and $1.7691 \mathrm{~h}^{-1}$ for AcCO).

In SR, a slight decrease can be seen in the $\mathrm{H}_{2}$ selectivity and $\mathrm{H}_{2}$ concentrations, together with a slight increase in the $\mathrm{CH}_{4}$ and $\mathrm{CO}_{2}$ concentrations, as the space velocity increases (Fig. 3). However, the effect of the space velocity on the $\mathrm{H}_{2}$ yield is much higher and so the decrease in $\mathrm{H}_{2}$ yield as the WHVS increases is substantial. García-Lario et al. [60] have suggested that the catalyst may suffer from low activity at high space velocity values, and this decrease in catalytic activity would be reflected in both the pre-breakthrough and the post-breakthrough steps. 

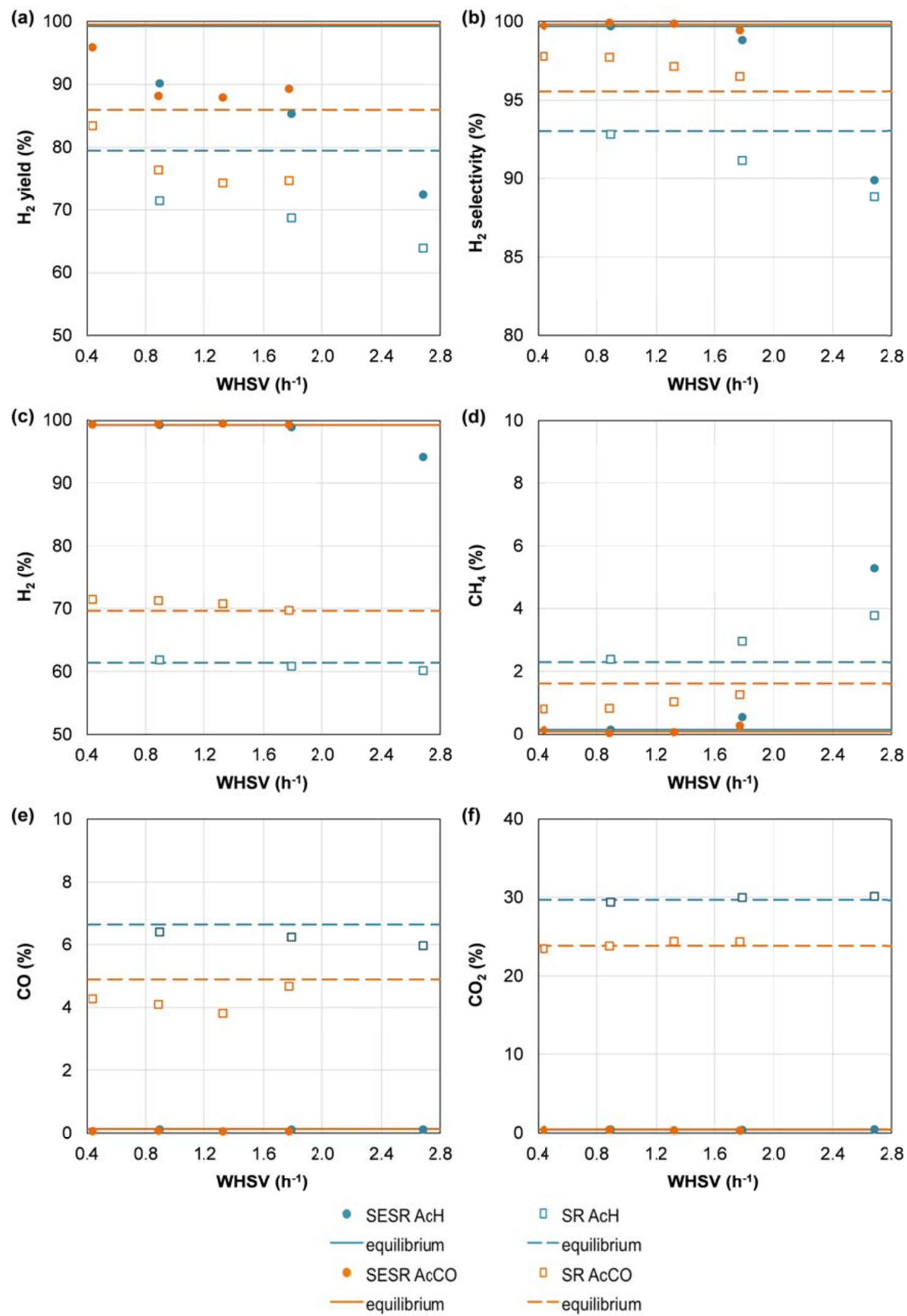

Fig. 3. Effect of the WHSV on the $\mathrm{H}_{2}$ yield (a), $\mathrm{H}_{2}$ selectivity (b) and $\mathrm{H}_{2}$ (c), $\mathrm{CH}_{4}$ (d), $\mathrm{CO}$ (e) and $\mathrm{CO}_{2}$ (f) concentrations during the SESR of $\mathrm{AcH}$ and $\mathrm{AcCO}$. Reaction conditions: $575^{\circ} \mathrm{C}$, steam $/ \mathrm{C}_{\mathrm{AcH}}=3 \mathrm{~mol} / \mathrm{mol}$, steam $/ \mathrm{C}_{\mathrm{AcCO}}=5 \mathrm{~mol} / \mathrm{mol}$, sorbent $/$ catalyst ratio $=5 \mathrm{~g} / \mathrm{g}, \mathrm{Pd} / \mathrm{Ni}-\mathrm{Co}$ HT catalyst and dolomite as sorbent. 


\subsection{SESR of the blends of AcH and AcCO}

To simulate the behavior of bio-oil during the SESR process, three mixtures of the two model compounds studied, acetic acid and acetone, were prepared containing 3:1, 1:1 and 1:3 mol AcH $/ \mathrm{mol} \mathrm{AcCO}$. To refer to the blends, the labels $3 \mathrm{AcH}: 1 \mathrm{AcCO}, 1 \mathrm{AcH}: 1 \mathrm{AcCO}$ and $1 \mathrm{AcH}: 3 \mathrm{AcCO}$, respectively, were used. SESR experiments with the blends of model compounds were carried out at temperatures of $475-675^{\circ} \mathrm{C}$. The feed rate of the blend solutions was $5 \mathrm{~g} \mathrm{~h}^{-1}$, and the experimental steam/C molar ratios were three times higher than the stoichiometric steam/C molar ratio of each individual blend, corresponding to steam $/ \mathrm{C}$ molar ratio values in the range of 3.667-4.636 and WHSV values in the range of 0.5080-0.7152 $\mathrm{h}^{-1}$.

Fig. 4 shows the $\mathrm{H}_{2}$ yield, $\mathrm{H}_{2}$ selectivity and $\mathrm{H}_{2}$ concentration as a function of the temperature during the SESR of each of the blends studied. As can be seen, the effect of the temperature on the SESR of the blends of $\mathrm{AcH}$ and $\mathrm{AcCO}$ is similar to that of the individual model compounds.

In general, the blended samples reflect the behavior of the individual model compounds. As in the case of the individual compounds, the $\mathrm{H}_{2}$ yield (Fig. 4a) of the blends increases with the reaction temperature until it reaches a maximum (at $625^{\circ} \mathrm{C}$ ), and then it decreases. The maximum $\mathrm{H}_{2}$ yield values are $92.44 \%$ and $95.90 \%$ for $\mathrm{AcH}$ and $\mathrm{AcCO}$, respectively. However, slightly lower values were obtained in the blends, i.e., $91.51 \%$ for $3 \mathrm{AcH}: 1 \mathrm{AcCO}, 88.85 \%$ for $1 \mathrm{AcH}: 1 \mathrm{AcCO}$ and $86.44 \%$ for $1 \mathrm{AcH}: 3 \mathrm{AcCO}$. In general, there is a slight decrease in $\mathrm{H}_{2}$ yield as the proportion of $\mathrm{AcCO}$ in the blend increases. It seems to indicate that some interaction effect between the components of the blends occurred, which slightly hindered the conversion of the blend. In the case of $\mathrm{H}_{2}$ selectivity (Fig. $4 \mathrm{~b}$ ), very high values (>99.5\%) at temperatures between $575-675^{\circ} \mathrm{C}$ were obtained for all three blends, as occurred with the individual compounds.

The $\mathrm{H}_{2}$ concentration (Fig. 4c) of the blends reaches a maximum value at $525{ }^{\circ} \mathrm{C}$ and then decreases as the reaction temperature increases, as in the case of the individual compounds. The maximum values are $99.29 \%$ and $99.75 \%$ for $\mathrm{AcH}$ and $\mathrm{AcCO}$, respectively, and similar to the maximum values obtained in the blends $(99.60 \%$ for $3 \mathrm{AcH}: 1 \mathrm{AcCO}, 99.77 \%$ for $1 \mathrm{AcH}: 1 \mathrm{AcCO}$ and $99.78 \%$ for $1 \mathrm{AcH}: 3 \mathrm{AcCO})$. 

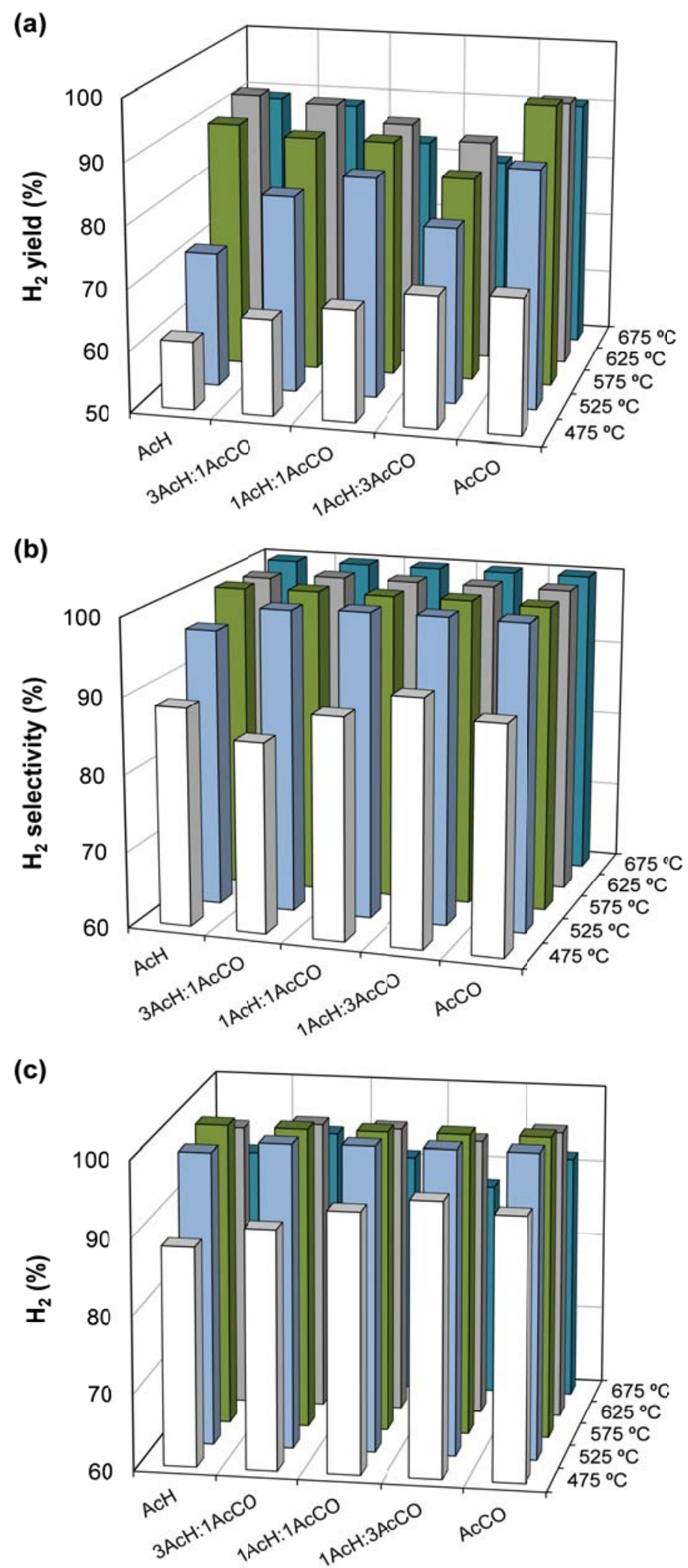

Fig. 4. $\mathrm{H}_{2}$ yield (a), $\mathrm{H}_{2}$ selectivity (b) and $\mathrm{H}_{2}$ concentration (c) during the SESR of blends of AcH and AcCO (3:1, 1:1 and 1:3 mol AcH $/ \mathrm{mol} \mathrm{AcCO}$ ) at different temperatures. Reaction conditions: steam $/ \mathrm{C}=3.667-4.636 \mathrm{~mol} / \mathrm{mol}$ and WHSV $=0.5080-0.7152 \mathrm{~h}^{-1}$ (total inlet liquid flow rate $=5 \mathrm{~g} \mathrm{~h}^{-1}$ ), sorbent/catalyst ratio $=5 \mathrm{~g} / \mathrm{g}, \mathrm{Pd} / \mathrm{Ni}-\mathrm{Co}$ HT catalyst and dolomite as sorbent. 
Fig. 5 shows the $\mathrm{CH}_{4}, \mathrm{CO}$ and $\mathrm{CO}_{2}$ concentrations as a function of temperature during the SESR of the blends. As with the individual compounds, the $\mathrm{CH}_{4}$ concentration is high at $475^{\circ} \mathrm{C}$ in the blends, but it decreases sharply at higher temperatures. At $525{ }^{\circ} \mathrm{C}$, low $\mathrm{CH}_{4}$ concentrations $(0.1-0.3 \%)$ are obtained for the blends, and they are lower than $0.1 \%$ at temperatures of 575 $675^{\circ} \mathrm{C}$. This shows that the $\mathrm{Pd} / \mathrm{Co}-\mathrm{Ni} \mathrm{HT}$ is an effective catalyst for suppressing the methanation reaction and/or for successfully catalyzing the methane steam reforming reaction during the SESR of blends of acetic acid and acetone. Also, as in the case of the individual model compounds, the $\mathrm{CO}$ and $\mathrm{CO}_{2}$ concentrations increase as the temperature increases from $525^{\circ} \mathrm{C}$ to $675^{\circ} \mathrm{C}$ and their values are quite similar to those of the individual compounds in the temperature range studied. However, at very high temperatures $\left(625-675^{\circ} \mathrm{C}\right)$ a slight increase in the $\mathrm{CO}$ and $\mathrm{CO}_{2}$ concentrations can be seen with the increase in the proportion of $\mathrm{AcCO}$ in the blend.

In summary, the results of the present work indicate that the blends of model compounds of bio-oil show similar results for the parameters studied than those of the individual compounds, acetic acid and acetone, except in the fact that lower $\mathrm{H}_{2}$ yield values, and slightly higher concentrations of $\mathrm{CO}$ and $\mathrm{CO}_{2}$ at the higher temperatures, are apparent in the blends compared to the individual compounds. Moreover, the $\mathrm{H}_{2}$ yield decreases, while the $\mathrm{CO}$ and $\mathrm{CO}_{2}$ concentrations increase slightly, as the proportion of $\mathrm{AcCO}$ in the blend increases.

As a basis for selecting the best conditions for the SESR of the blends, it should be borne in mind that the highest $\mathrm{H}_{2}$ yield values (86.4-91.5\%) were obtained at $625^{\circ} \mathrm{C}$ for all three blends. Under these conditions, high values of $\mathrm{H}_{2}$ selectivity were also obtained (99.9\%), but the $\mathrm{H}_{2}$ concentration was very low (96.1-97.4\%). $\mathrm{CO}$ and $\mathrm{CO}_{2}$ concentrations were also quite high (0.6-0.9\% and 1.8-3.0\%, respectively). The highest $\mathrm{H}_{2}$ concentrations (99.6-99.8\%) were obtained at $525^{\circ} \mathrm{C}$ for all three blends whereas the $\mathrm{H}_{2}$ yields decreased significantly (78.4$82.0 \%$ ). Therefore, if the aim is to achieve a high $\mathrm{H}_{2}$ concentration is aimed without excessively reducing the $\mathrm{H}_{2}$ yield, the optimum temperature for the SESR of the blends of model bio-oil compounds is $575{ }^{\circ} \mathrm{C}$, since at this temperature $\mathrm{H}_{2}$ yields of 83.6-88.6\%, together with $\mathrm{H}_{2}$ concentrations of $99.2-99.3 \%$, are obtained. 

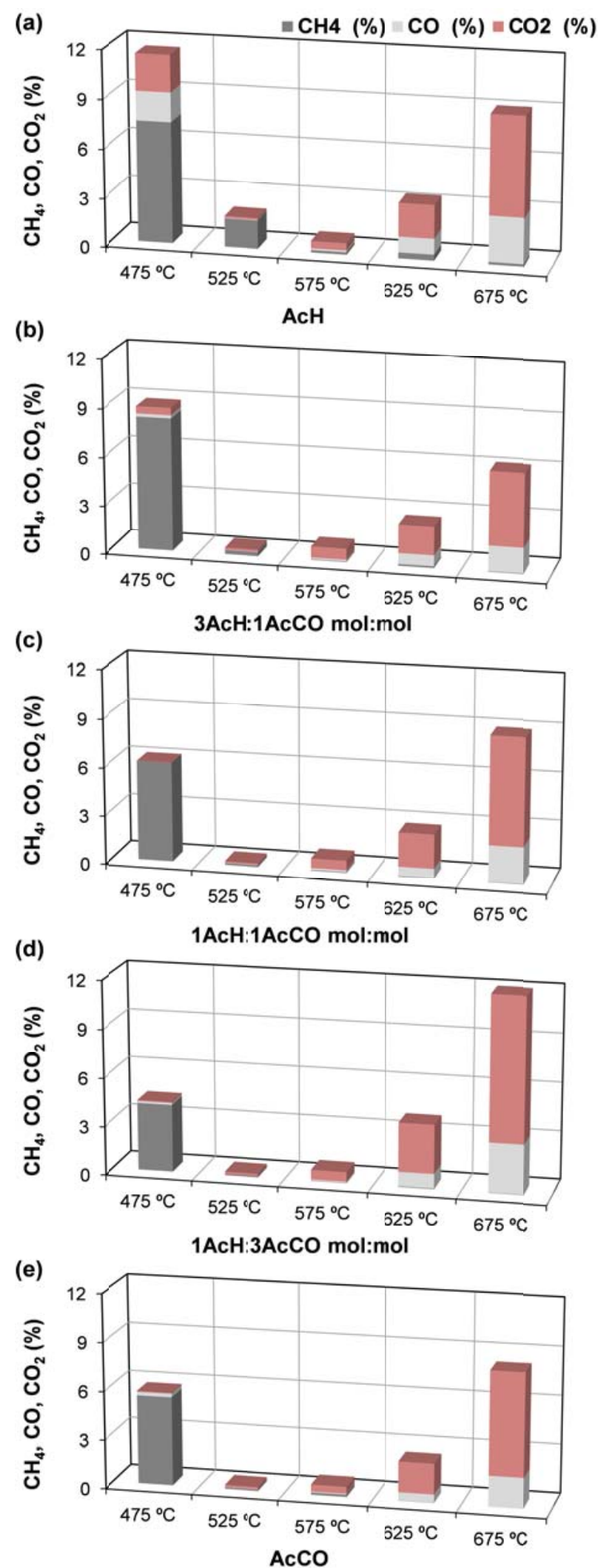

Fig. 5. $\mathrm{CH}_{4}, \mathrm{CO}$ and $\mathrm{CO}_{2}$ concentrations during the SESR of $\mathrm{AcH}$ (a), $3 \mathrm{AcH}: 1 \mathrm{AcCO}$ (b), $1 \mathrm{AcH}: 1 \mathrm{AcCO}$ (c), $1 \mathrm{AcH}: 3 \mathrm{AcCO}(\mathrm{d})$ and $\mathrm{AcCO}(\mathrm{e})$ at different temperatures. Reaction conditions: steam $/ \mathrm{C}=3.667-4.636 \mathrm{~mol} / \mathrm{mol}$ and WHSV $=0.5080-0.7152 \mathrm{~h}^{-1}$ (total inlet liquid flow rate $=5 \mathrm{~g} \mathrm{~h}^{-1}$ ), sorbent/catalyst ratio $=5 \mathrm{~g} / \mathrm{g}, \mathrm{Pd} / \mathrm{Ni}-\mathrm{Co}$ HT catalyst and dolomite as sorbent. 


\section{Conclusions}

The operational parameters for the sorption enhanced steam reforming of acetic acid and acetone, two representative model compounds of bio-oil obtained from the fast pyrolysis of biomass, as well as their blends were studied in a fluidized bed reactor. The results show that acetic acid, acetone and their blends can be efficiently reformed to hydrogen over a $\mathrm{Pd} / \mathrm{Ni}-\mathrm{Co}$ HT catalyst and using dolomite as $\mathrm{CO}_{2}$ sorbent in a SESR process. The $\mathrm{H}_{2}$ yield and $\mathrm{H}_{2}$ concentration increase with temperature up to a maximum value, and then they decrease. The $\mathrm{H}_{2}$ selectivity values are very high in the temperature range of $525-675^{\circ} \mathrm{C}$. The $\mathrm{CH}_{4}$ concentration decreases as the temperature increases, while the $\mathrm{CO}$ and $\mathrm{CO}_{2}$ concentrations increase with temperature. In general, equilibrium for the SESR process was reached at temperatures in the 525-725 ${ }^{\circ} \mathrm{C}$ range. $\mathrm{H}_{2}$ yield, $\mathrm{H}_{2}$ selectivity and $\mathrm{H}_{2}$ concentration all increase as the steam/C molar ratio increases, whilst they decrease when WHSV increases. The positive effect of increasing the steam/C ratio is ascribed to the enhanced steam reforming and WGS reactions, whereas the negative effect of increasing WHSV is the result of a lower fuel conversion due to a shorter contact time.

The SESR at $575^{\circ} \mathrm{C}$ of the model compounds of bio-oil and their blends using $\mathrm{Pd} / \mathrm{Co}-\mathrm{Ni}$ $\mathrm{HT}$ as catalyst and calcined dolomite as $\mathrm{CO}_{2}$ sorbent (sorbent/catalyst ratio of $5 \mathrm{~g} / \mathrm{g}$ ) under the conditions of the present study gives rise to $\mathrm{H}_{2}$ purity values of 99.2-99.4\% and $\mathrm{H}_{2}$ selectivity values of 99.7-99.9\%. The SESR of blends of model compounds of bio-oil show similar results for the parameters studied that those for the individual model compounds, acetic acid and acetone, except in that lower $\mathrm{H}_{2}$ yield values are obtained from the SESR of the blends (83.3$88.6 \%$ ) compared to the individual model compounds (90.2-95.9\%). This effect is more marked as the proportion of $\mathrm{AcCO}$ in the blend increases.

\section{Acknowledgements}

The authors thank Franefoss Miljøkalk A/S (Norway) for supplying Arctic dolomite. This work was carried out with financial support from the Spanish MINECO (Project ENE201453515-P), co-financed by the European Regional Development Fund (ERDF) and the Principado de Asturias (PCTI 2013-2017, GRUPIN14-079). G. Esteban-Díez acknowledges funding from the Government of the Principado de Asturias (Severo Ochoa program).

\section{References}

[1] Kathe MV, Empfield A, Na J, Blair E, Fan L-S. Hydrogen production from natural gas using an iron-based chemical looping technology: Thermodynamic simulations and process system analysis. Appl Energy. 2016;165:183-201. 
[2] Hafizi A, Rahimpour MR, Hassanajili S. Hydrogen production via chemical looping steam methane reforming process: Effect of cerium and calcium promoters on the performance of $\mathrm{Fe}_{2} \mathrm{O}_{3} / \mathrm{Al}_{2} \mathrm{O}_{3}$ oxygen carrier. Appl Energy. 2016;165:685-94.

[3] Hosseini SE, Wahid MA. Hydrogen production from renewable and sustainable energy resources: Promising green energy carrier for clean development. Renew Sust Energ Rev. 2016;57:850-66.

[4] Shen D, Jin W, Hu J, Xiao R, Luo K. An overview on fast pyrolysis of the main constituents in lignocellulosic biomass to valued-added chemicals: Structures, pathways and interactions. Renew Sust Energ Rev. 2015;51:761-74.

[5] Kan T, Strezov V, Evans TJ. Lignocellulosic biomass pyrolysis: A review of product properties and effects of pyrolysis parameters. Renew Sust Energ Rev. 2016;57:1126-40.

[6] Czernik S, Bridgwater AV. Overview of Applications of Biomass Fast Pyrolysis Oil. Energy Fuels. 2004;18:590-8.

[7] Rioche C, Kulkarni S, Meunier FC, Breen JP, Burch R. Steam reforming of model compounds and fast pyrolysis bio-oil on supported noble metal catalysts. Appl Catal B-Environ. 2005;61:130-9.

[8] Czernik S, French R, Feik C, Chornet E. Hydrogen by Catalytic Steam Reforming of Liquid Byproducts from Biomass Thermoconversion Processes. Ind Eng Chem Res. 2002;41:4209-15.

[9] Wang D, Czernik S, Chornet E. Production of Hydrogen from Biomass by Catalytic Steam Reforming of Fast Pyrolysis Oils. Energy Fuels. 1998;12:19-24.

[10] Bimbela F, Chen D, Ruiz J, García L, Arauzo J. Ni/Al coprecipitated catalysts modified with magnesium and copper for the catalytic steam reforming of model compounds from biomass pyrolysis liquids. Appl Catal B-Environ. 2012;119-120:1-12.

[11] Li Z, Hu X, Zhang L, Lu G. Renewable hydrogen production by a mild-temperature steam reforming of the model compound acetic acid derived from bio-oil. J Mol Catal A: Chem. 2012;355:123-33.

[12] Kechagiopoulos PN, Voutetakis SS, Lemonidou AA, Vasalos IA. Hydrogen Production via Steam Reforming of the Aqueous Phase of Bio-Oil in a Fixed Bed Reactor. Energy Fuels. 2006;20:2155-63.

[13] Wu C, Sui M, Yan YJ. A Comparison of Steam Reforming of Two Model Bio-Oil Fractions. Chemical Engineering \& Technology. 2008;31:1748-53.

[14] Bimbela F, Oliva M, Ruiz J, García L, Arauzo J. Hydrogen production via catalytic steam reforming of the aqueous fraction of bio-oil using nickel-based coprecipitated catalysts. Int $\mathbf{J}$ Hydrogen Energy. 2013;38:14476-87. 
[15] Sengupta P, Khan A, Zahid MA, Ibrahim H, Idem R. Evaluation of the Catalytic Activity of Various $5 \mathrm{Ni} / \mathrm{Ce} 0.5 \mathrm{Zr} 0.33 \mathrm{M} 0.17 \mathrm{O} 2-\delta$ Catalysts for Hydrogen Production by the Steam Reforming of a Mixture of Oxygenated Hydrocarbons. Energy Fuels. 2012;26:816-28.

[16] Johnsen K, Ryu HJ, Grace JR, Lim CJ. Sorption-enhanced steam reforming of methane in a fluidized bed reactor with dolomite as $\mathrm{CO}_{2}$-acceptor. Chem Eng Sci. 2006;61:1195-202.

[17] Ayalur Chattanathan S, Adhikari S, Abdoulmoumine N. A review on current status of hydrogen production from bio-oil. Renew Sust Energ Rev. 2012;16:2366-72.

[18] Kwak BS, Lee JS, Lee JS, Choi B-H, Ji MJ, Kang M. Hydrogen-rich gas production from ethanol steam reforming over $\mathrm{Ni} / \mathrm{Ga} / \mathrm{Mg} /$ Zeolite $\mathrm{Y}$ catalysts at mild temperature. Appl Energy. 2011;88:4366-75.

[19] Balasubramanian B, Lopez Ortiz A, Kaytakoglu S, Harrison DP. Hydrogen from methane in a single-step process. Chem Eng Sci. 1999;54:3543-52.

[20] He L, Chen D. Single-Stage Production of Highly Concentrated Hydrogen from BiomassDerived Syngas. ChemSusChem. 2010;3:1169-71.

[21] Ochoa-Fernandez E, Haugen G, Zhao T, Ronning M, Aartun I, Borresen B, et al. Process design simulation of $\mathrm{H}_{2}$ production by sorption enhanced steam methane reforming: evaluation of potential $\mathrm{CO}_{2}$ acceptors. Green Chemistry. 2007;9:654-62.

[22] Chen S, Xiang W, Wang D, Xue Z. Incorporating IGCC and $\mathrm{CaO}$ sorption-enhanced process for power generation with $\mathrm{CO}_{2}$ capture. Appl Energy. 2012;95:285-94.

[23] Barelli L, Bidini G, Gallorini F. SE-SR with sorbents based on calcium aluminates: Process optimization. Appl Energy. 2015;143:110-8.

[24] Martínez I, Romano MC, Fernández JR, Chiesa P, Murillo R, Abanades JC. Process design of a hydrogen production plant from natural gas with $\mathrm{CO}_{2}$ capture based on a novel $\mathrm{Ca} / \mathrm{Cu}$ chemical loop. Appl Energy. 2014;114:192-208.

[25] Cho WC, Lee DY, Seo MW, Kim SD, Kang K, Bae KK, et al. Continuous operation characteristics of chemical looping hydrogen production system. Appl Energy. 2014;113:166774.

[26] Dou B, Song Y, Wang C, Chen H, Yang M, Xu Y. Hydrogen production by enhancedsorption chemical looping steam reforming of glycerol in moving-bed reactors. Appl Energy. 2014;130:342-9.

[27] Abanades JC. The maximum capture efficiency of $\mathrm{CO}_{2}$ using a carbonation/calcination cycle of $\mathrm{CaO} / \mathrm{CaCO}_{3}$. Chem Eng J. 2002;90:303-6.

[28] Yi KB, Harrison DP. Low-Pressure Sorption-Enhanced Hydrogen Production. Ind Eng Chem Res. 2005;44:1665-9. 
[29] Martavaltzi CS, Lemonidou AA. xHydrogen production via sorption enhanced reforming of methane: Development of a novel hybrid material-reforming catalyst and $\mathrm{CO}_{2}$ sorbent. Chem Eng Sci. 2010;65:4134-40.

[30] Arstad B, Blom R, Bakken E, Dahl I, Jakobsen JP, Røkke P. Sorption-enhanced methane steam reforming in a circulating fluidized bed reactor system. Energy Procedia. 2009;1:715-20.

[31] Xie M, Zhou Z, Qi Y, Cheng Z, Yuan W. Sorption-enhanced steam methane reforming by in situ $\mathrm{CO}_{2}$ capture on a $\mathrm{CaO}-\mathrm{Ca}_{9} \mathrm{Al}_{6} \mathrm{O}_{18}$ sorbent. Chem Eng J. 2012;207-208:142-50.

[32] Radfarnia HR, Iliuta MC. Hydrogen production by sorption-enhanced steam methane reforming process using $\mathrm{CaO}-\mathrm{Zr} / \mathrm{Ni}$ bifunctional sorbent-catalyst. Chemical Engineering and Processing: Process Intensification. 2014;86:96-103.

[33] Beaver MG, Caram HS, Sircar S. Sorption enhanced reaction process for direct production of fuel-cell grade hydrogen by low temperature catalytic steam-methane reforming. J Power Sources. 2010;195:1998-2002.

[34] Harrison DP. Sorption-Enhanced Hydrogen Production: A Review. Ind Eng Chem Res. 2008;47:6486-501.

[35] García-Lario AL, Aznar M, Martinez I, Grasa GS, Murillo R. Experimental study of the application of a $\mathrm{NiO} / \mathrm{NiAl}_{2} \mathrm{O}_{4}$ catalyst and a CaO-based synthetic sorbent on the Sorption Enhanced Reforming process. Int J Hydrogen Energy. 2015;40:219-32.

[36] He L, Berntsen H, Chen D. Approaching Sustainable $\mathrm{H}_{2}$ Production: Sorption Enhanced Steam Reforming of Ethanol. J Phys Chem A. 2010;114:3834-44.

[37] Cunha AF, Wu YJ, Santos JC, Rodrigues AE. Sorption enhanced steam reforming of ethanol on hydrotalcite-like compounds impregnated with active copper. Chem Eng Res Des. 2013;91:581-92.

[38] Aceves Olivas DY, Baray Guerrero MR, Escobedo Bretado MA, Marques da Silva Paula M, Salinas Gutiérrez J, Guzmán Velderrain V, et al. Enhanced ethanol steam reforming by CO2 absorption using $\mathrm{CaO}, \mathrm{CaO} * \mathrm{MgO}$ or Na2ZrO3. Int J Hydrogen Energy. 2014;39:16595-607.

[39] Dou B, Wang C, Chen H, Song Y, Xie B. Continuous sorption-enhanced steam reforming of glycerol to high-purity hydrogen production. Int J Hydrogen Energy. 2013;38:11902-9.

[40] He L, Parra JMS, Blekkan EA, Chen D. Towards efficient hydrogen production from glycerol by sorption enhanced steam reforming. Energy Environ Sci. 2010;3:1046-56.

[41] Fermoso J, He L, Chen D. Production of high purity hydrogen by sorption enhanced steam reforming of crude glycerol. Int J Hydrogen Energy. 2012;37:14047-54.

[42] Dou B, Dupont V, Rickett G, Blakeman N, Williams PT, Chen H, et al. Hydrogen production by sorption-enhanced steam reforming of glycerol. Bioresour Technol. 2009;100:3540-7. 
[43] He L, Chen D. Hydrogen Production from Glucose and Sorbitol by Sorption-Enhanced Steam Reforming: Challenges and Promises. ChemSusChem. 2012;5:587-95.

[44] Pimenidou P, Rickett G, Dupont V, Twigg MV. High purity $\mathrm{H}_{2}$ by sorption-enhanced chemical looping reforming of waste cooking oil in a packed bed reactor. Bioresour Technol. 2010;101:9279-86.

[45] Han L, Wang Q, Luo Z, Rong N, Deng G. $\mathrm{H}_{2}$ rich gas production via pressurized fluidized bed gasification of sawdust with in situ $\mathrm{CO}_{2}$ capture. Appl Energy. 2013;109:36-43.

[46] Noor T, Gil MV, Chen D. Production of fuel-cell grade hydrogen by sorption enhanced water gas shift reaction using Pd/Ni-Co catalysts. Appl Catal B-Environ. 2014;150-151:585-95.

[47] Fermoso J, Rubiera F, Chen D. Sorption enhanced catalytic steam gasification process: a direct route from lignocellulosic biomass to high purity hydrogen. Energy Environ Sci. 2012;5:6358-67.

[48] Fermoso J, Gil MV, Rubiera F, Chen D. Multifunctional Pd/Ni-Co Catalyst for Hydrogen Production by Chemical Looping Coupled With Steam Reforming of Acetic Acid. ChemSusChem. 2014;7:3063-77.

[49] Galdámez JR, García L, Bilbao R. Hydrogen Production by Steam Reforming of Bio-Oil Using Coprecipitated Ni-Al Catalysts. Acetic Acid as a Model Compound. Energy Fuels. 2005;19:1133-42.

[50] Xie H, Yu Q, Wang K, Shi X, Li X. Thermodynamic analysis of hydrogen production from model compounds of bio-oil through steam reforming. Environmental Progress \& Sustainable Energy. 2014;33:1008-16.

[51] Xie H, Yu Q, Yao X, Duan W, Zuo Z, Qin Q. Hydrogen production via steam reforming of bio-oil model compounds over supported nickel catalysts. Journal of Energy Chemistry. 2015;24:299-308.

[52] Xie H, Yu Q, Wei M, Duan W, Yao X, Qin Q, et al. Hydrogen production from steam reforming of simulated bio-oil over $\mathrm{Ce}-\mathrm{Ni} / \mathrm{Co}$ catalyst with in continuous $\mathrm{CO} 2$ capture. Int $\mathrm{J}$ Hydrogen Energy. 2015;40:1420-8.

[53] Yan C-F, Hu E-Y, Cai C-L. Hydrogen production from bio-oil aqueous fraction with in situ carbon dioxide capture. Int J Hydrogen Energy. 2010;35:2612-6.

[54] Xie H, Yu Q, Zuo Z, Han Z, Yao X, Qin Q. Hydrogen production via sorption-enhanced catalytic steam reforming of bio-oil. Int J Hydrogen Energy. 2016;41:2345-53.

[55] He L, Berntsen H, Ochoa-Fernández E, Walmsley J, Blekkan E, Chen D. Co-Ni Catalysts Derived from Hydrotalcite-Like Materials for Hydrogen Production by Ethanol Steam Reforming. Top Catal. 2009;52:206-17. 
[56] Gil MV, Fermoso J, Rubiera F, Chen D. $\mathrm{H}_{2}$ production by sorption enhanced steam reforming of biomass-derived bio-oil in a fluidized bed reactor: An assessment of the effect of operation variables using response surface methodology. Catal Today. 2015;242, Part A:19-34.

[57] Wang Y, Chao Z, Jakobsen H. Numerical study of hydrogen production by the sorptionenhanced steam methane reforming process with online $\mathrm{CO}_{2}$ capture as operated in fluidized bed reactors. Clean Technol Environ Policy. 2011;13:559-65.

[58] He L, Yang J, Chen D. Chapter 6 - Hydrogen from Biomass: Advances in Thermochemical Processes. In: Gandía LM, Arzamendi G, Diéguez PM, editors. Renewable Hydrogen Technologies, Amsterdam: Elsevier; 2013. p. 111-33.

[59] Comas J, Laborde M, Amadeo N. Thermodynamic analysis of hydrogen production from ethanol using $\mathrm{CaO}$ as a $\mathrm{CO}_{2}$ sorbent. J Power Sources. 2004;138:61-7.

[60] García-Lario AL, Aznar M, Grasa GS, Murillo R. Evaluation of process variables on the performance of Sorption Enhanced Methane Reforming. J Power Sources. 2015;285:90-9. 